\title{
STUDY OF THE INTERACTION OF TRIETHOXYSILANE WITH LINOLEIC ACID AS WATER REPELLENT FOR USE IN ORNAMENTAL STONES
}

\author{
J. C. G.CORREIA ${ }^{*}$., L. V. B. de CAMPOS*., A. N. M. CARAUTA., ${ }^{* * *}$ \\ "Centro de Tecnologia Mineral - CETEM/MCTIC, RJ \\ ${ }^{* *}$ Fundação Técnico Educacional Souza Marques - FTESM, RJ \\ jguedes@cetem.gov.br*
}

Received 18/10/2017 - Accepted 10/11/2017

DOI: $10.15628 /$ holos.2017.6443

\begin{abstract}
Using the compound triethoxysilane, which can be synthesized from ethanol and silicon metal, and the octadecanol which can came from the hydrogenation and reduction of linoleic acid found in jatropha oil, the present work aims, through molecular modeling, study the interactions between these compounds to subsequently use the results obtained for the synthesis of the triethoxy(octadecoxy) silane compound, which can be consider sustainable since much of its raw material can came from renewable sources like
\end{abstract}

sugarcane and jatropha curca's oil. Duly designed to fulfill the specific function of be used as a water repellent in the protection of ornamental stones. With three ethoxy groups for the anchorage in the stone substratum and natural polymerization after application in the stone or monument, and a C18 type hydrophobic saturated long chain group which avoids the absorption of water by capillarity and protects against physical, chemical and biological weathering that may occur due to the action of time and the absorption of water.

KEYWORDS: Organossilane, Hydro-repellent, Ornamental Stone.

\section{RESUMO}

Utilizando o composto trietoxisilano, que pode ser sintetizado a partir de etanol e silício metálico, e o álcool octadecanol proveniente da hidrogenação e redução do ácido linoleico encontrado no óleo de pinhão manso, o presente trabalho visa, via modelagem molecular, estudar as interações entre estes compostos a fim de utilizar posteriormente o resultado obtido para a síntese na pratica do composto trietoxi (octadecoxi)silano, que pode ser considerado sustentável pois grande parte da sua matéria prima pode vir de fontes renováveis como a cana de açúcar e o óleo de pinhão manso. Devidamente desenhado para cumprir com sua função específica de ser utilizado como hidrofugante na proteção de rochas ornamentais, o composto trietoxioctadecilsilano possui três grupos alcóxi para um eficiente ancoramento no substrato rochoso e polimerização natural promovida pelo contato com o ar atmosférico, após a aplicação na rocha ou monumento, possui também um radical de cadeia longa saturada hidrofóbica do tipo C18, que tanto evita a absorção de água por capilaridade, quanto protege contra intempéries físicas, químicas e biológicas que possam se apresentar devido à ação do tempo e da absorção de água.

KEYWORDS: Organosilano, Hidrofugante, Rocha Ornamental. 


\section{INTRODUCTION}

Current research in the biorefinery area focuses on fostering new industries to convert biomass into a variety of products, including those that may eventually replace petrochemicals. Two of the most promising emerging platforms in biorefinery are the sugar and the thermochemical platforms. Biorefineries of sugar platforms convert biomass into different types of sugars by fermentation or other biological process in various chemical and / or fuel platforms (ethanol). According to Companhia Nacional de Abastecimento - Conab, Brazilian ethanol production in 2009 was approximately 28 billion liters, demanding 350 million tons of sugarcane and generating about 79 million tons of bagasse.

Jatropha curcas L. belonging to the euphorbiaceous family, the same as castor bean, is an oleaginous oil content that can vary from $40-60 \%$. It has been motivated by several studies because it is a plant with great potential as a raw material in the production of biodiesel and other compounds. Among the oilseeds, jatropha has been highlighted as a perennial, rustic and easily adapted plant in soil and climate conditions (SATURNINO et al., 2005). One of the great advantages of jatropha is its long productive cycle that can reach 40 years and maintain a productivity average of 2 tons / ha, besides being a crop that can develop in small farms with the hand- (PURCINO and DRUMMOND, 1986 cited by ARRUDA et al., 2004).

The extraction methods used in the past were very simplified and the products obtained from these were not always $100 \%$ pure oils. In addition, the characteristics of an oil may change according to the method used, since its chemical properties may be totally altered depending on the conditions to which it is subjected when a particular technique is used (SILVA, 2006). In the first decades of the 20th century, oilseed presses were used, which, while extracting good quality oil, left residues in the solid material. Such residues implied the loss of oil, affecting the quality of the pie, which is also one of the effluent products of the extractor (BOSS, 2000). Currently, the amount of solvent used by the industries in conventional extraction processes is estimated at approximately one million tons per year (MENDES et al., 2007).

Current forecasts indicate that by 2025 , more than $30 \%$ of the raw materials for the chemical industry will be produced from renewable sources. To achieve these goals, the development of new technologies for biorefinery platforms, such as biorefineries for the conversion of lignocellulosic (LFC) based raw materials, with an emphasis on the efficient separation of lignin, cellulose and hemicellulose, are indispensable. Other major areas of intense research activity are advances in thermal, chemical, mechanical and biological processes. The next generation of biorefineries, also known as phase III biorefineries, is also at the top of the list in research agendas, which will facilitate true integration of different feedstocks and technologies for the development of a variety of custom products. Although functional products such as fiberreinforced composites and starch / protein products are now available from renewable sources and can even be found on the market, current research focuses on the development of chemical platforms and syngas (synthetic gas) for the consistent development of structured compounds as essential chemical constituents essential for the industry such as those of feedstock for the production of organosilanes. 
Dow Corning pioneered the development of organosilane technology for more than 50 years offering a new class of materials with new physical properties and chemical properties, such as siloxanes and silanes. This research has led the market to a new industry based on the synergy between organic and inorganic chemistry. The value of silane coupling agents was first discovered in the 1940s with the development of glass fiber reinforced polyester composites. When fabricated initially, these composites were very strong, but their strength decreased rapidly during aging of the material. This weakening was caused by a break in the bond between the glass and the resin. Seeking a solution, researchers have discovered organofunctional silanes, chemical silicon hybrid compounds that contain both an organic and an inorganic part in the same molecule. A very small amount of an organofunctional alkoxysilane interacting at the glass-resin interface not only significantly increased the initial strength of the compound, but also resulted in a retention of that force over time. Subsequently, other applications for organosilanes were discovered. For example: in mineral and filler treatment for reinforcement of composites, adhesion of paints, development of water repellents and protection of surfaces.

The ornamental rocks, by their varieties of colors, are widely used by the industry as raw material in the making of statues, monuments, etc. These rocks, especially in external environments, suffer from weathering, which is nothing more than the wear of the rock caused by external factors be they physical, chemical or biological. The main problem caused by weathering is the absorption of water, either through direct contact during rainfall, capillarity and / or adsorption of water particles present in the air. (BARBUTTI et al, 2014). Therefore, the development of a product that acts as a protective material for the rock becomes necessary, since the fundamental characteristic of this rock is to make the surface of the rock hydrophobic, and, in addition, to be able to drastically reduce natural wear of the mineral without changing its physical characteristics.

Using all this information, besides many others and through computational simulations, molecular modeling is an extremely important tool in helping experimental problems, allowing the understanding of phenomena at a molecular and electronic level. Thus, the modeling is able to provide very valuable information regarding the interaction between the focus molecules of this study and the results of these calculations at hand it is possible to predict the optimal conditions for the synthesis of the final compound, triethoxyoctadecylsilane, as well as electronic properties and molecular mechanisms, reaction mechanisms and possible transition states, etc.

Within molecular modeling there are several methods of calculation, including: ab initio, DFT (Density Functional Theory), semi-empirical or empirical. The choice of methods depends on the atomic or molecular properties which is best described and also on the desired calculation time. In this work, an empirical method was used with the COMPASS force field for the first optimization of the molecules, this method being totally parameterized with values obtained experimentally and considering only the classical mechanics. A semi-empirical method still contains some experimental parameters, and the difference for the empirical is in the fact that some of its energetic parameters are calculated at the quantum level. Among the semi-empirical methods are the widely used functional AM1 and the PM6 which is a newer functional and has parameters for several heavier element atoms. 


\section{METHODOLOGY}

\subsection{Construction and optimization of structures}

The structures were designed with the GaussView 5.0.8 graphics package After the construction were submitted to a geometric optimization through the molecular mechanics method, using the force field DREIDING, in the FORCITE module, present in the program Materials Studio 4.3.0.0 .

\subsection{Molecular dynamics}

After the optimization of geometry, the molecular dynamics were performed for each structure under the following conditions: fixed temperature at $298 \mathrm{~K}$, dynamic time of 1000 ps and DREIDING force field. In the analysis of the trajectory calculated by the molecular dynamics, the first 1000 structures that correspond to the beginning of the dynamics, where the system is still energetically unstable, were discarded. The other structures were placed in increasing order of energy, selecting the ten structures that had lower energy, that for each target molecule of this study.

\subsection{Frequency calculation and optimization by quantum methods}

The ten selected structures were again subjected to a second geometry optimization to select the most stable structure, besides the frequency calculation. The frequency and optimization of each structure were calculated by semi-empirical method PM6 in software MOPAC2016 Frequency calculation was necessary to ensure that the structures were minimal energy and not transition states. After this second optimization, the lowest energy structure of each molecule was obtained.

\subsection{Interaction triethoxysilane - octadecanol}

With the most stable structures already selected in the previous step, systems were constructed in which these molecules were together in the same reaction environment and in different positions from oriented approaches between the structures with distances always equal to $5 \mathrm{~A}$ between the structures. Next, a semi-empirical calculation was performed with the systems in the MOPAC2016 software using the Hamiltonian PM6.

\section{RESULTS AND DISCUSSIONS}

Table 1 shows the result of the total energy calculated for each molecule studied in this work besides the system with the two joints. According to the energy variation (DE) obtained, the interaction between the octadecanol compounds and triethoxysilane is favorable.

Table 1. Energies obtained by the PM6 method.

\begin{tabular}{c|c|c}
\hline Molecules & $\begin{array}{c}\text { Energy } \\
(\mathrm{kcal} / \mathrm{mol})\end{array}$ & $\begin{array}{c}\Delta \text { Energy } \\
(\mathrm{kcal} / \mathrm{mol})\end{array}$ \\
\hline
\end{tabular}




\begin{tabular}{l|c|c}
\hline Triethoxysilane & $-247,70$ & - \\
Octadecanol & $-134,62$ & - \\
Triethoxysilane + & $-387,31$ & $-4,99$ \\
Octadecanol System & & \\
\hline
\end{tabular}

Different interaction positions between the reactants (Figures 1, 2 and 3) were also tested and all their respective results indicate that the triethoxysilane molecule tends to spin to undergo a nucleophilic attack by octadecanol, just opposite the bound hydrogen to silicon. The bond length, which has also been evaluated, indicates that the bond between the silicon and the oxygen bound to the $\mathrm{C} 18$ radical is shorter in relation to the bonding of the ethoxy groups with the same silicon, probably due to the great inductive effect of the radical C18.

In addition, the freedom of movement that the Si-O bond allows to the $\mathrm{C} 18$ moiety increases its hydrophobic power, since both chain fold and random motions in all directions further shield the substrate in which the triethoxy groups are adsorbed.

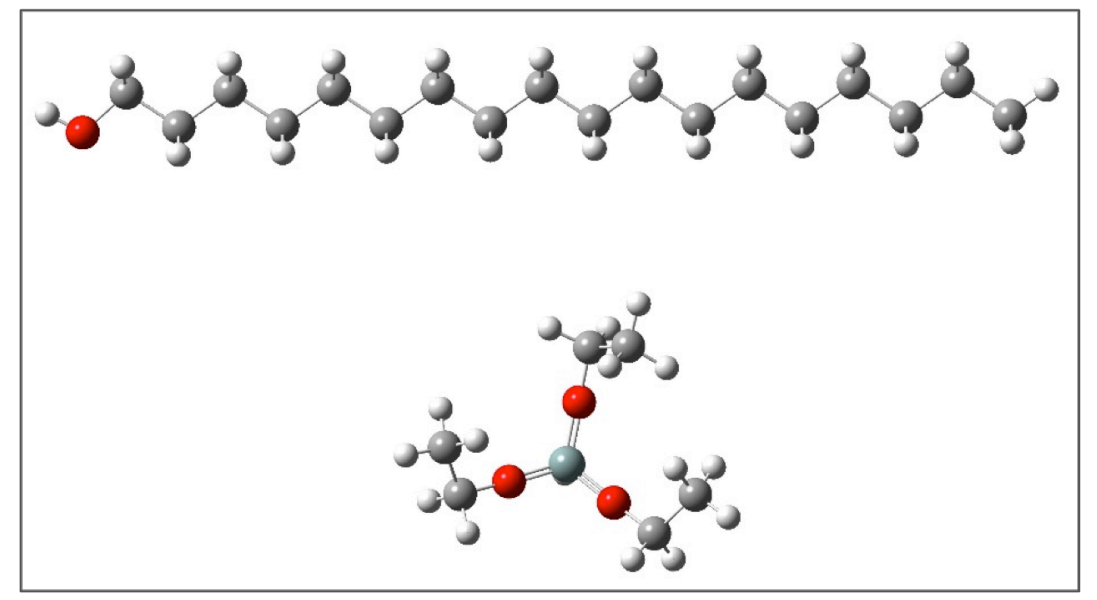

Figure 1: First tested position of the interaction between octadecanol above in the figure and the triethoxysilane below. 


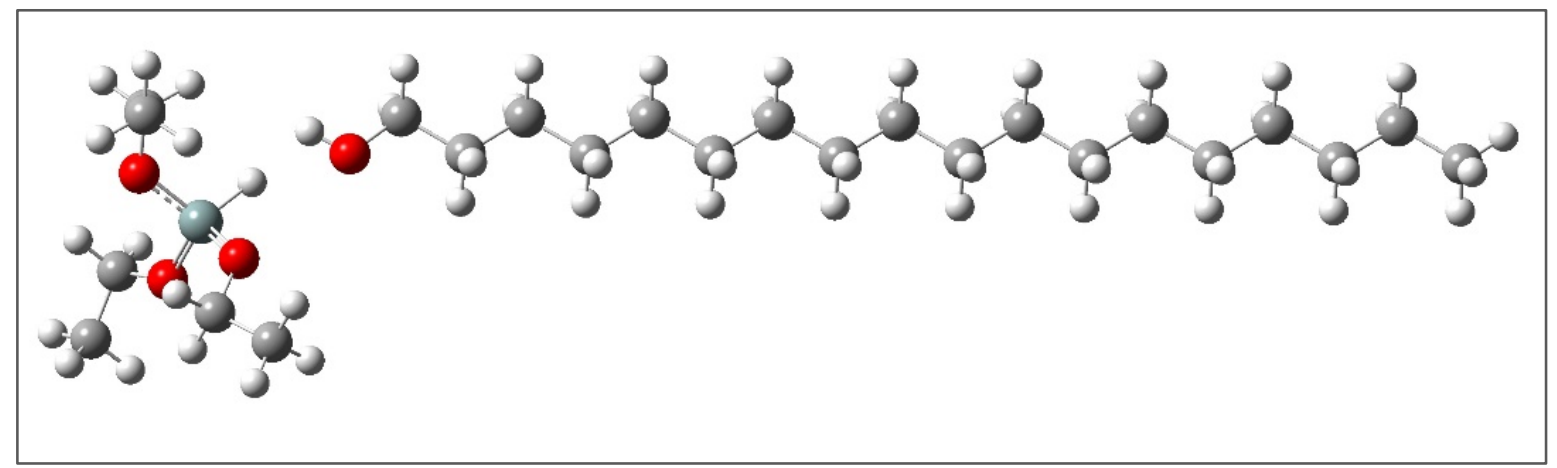

Figure 2: Second tested position of the interaction between the direct octadecanol and the left triethoxysilane. It may be noted that the hydrogen of the triethoxysilane is purposely turned to the hydroxyl of octadecanol.

In Figure 1, there was no conversion in the calculation. In Figure 2, the total energy obtained was $-385.7474 \mathrm{Kcal} . \mathrm{mol}-1$ and a tendency of the triethoxysilane to be rotated was observed, indicating that the best interaction would be on the opposite side to the hydrogen connected to the silicon.

Figu

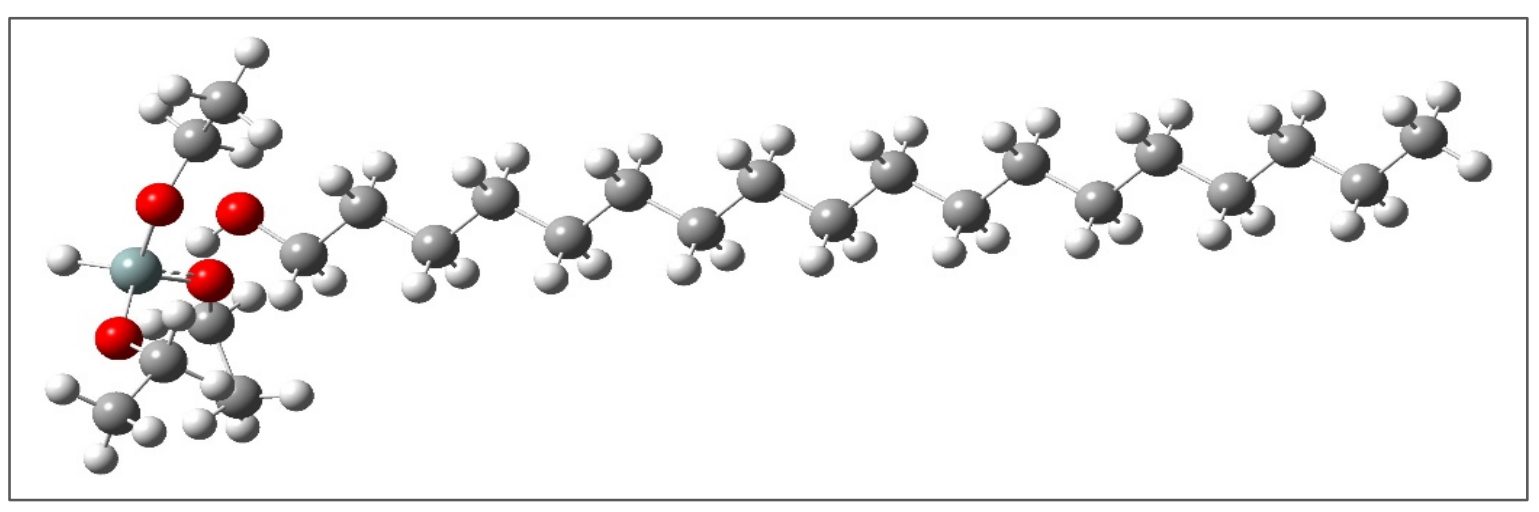

re 3: Third tested position of the interaction between the right octadecanol and the left triethoxysilane. Note that this time the silicon-bound hydrogen is facing the hydroxyl-opposite side of octadecanol.

In Figure 3, the total energy obtained was $-387.3171 \mathrm{Kcal} . \mathrm{mol}-1$ was again observed the reaction tendency on the opposite side to the silicon-bound hydrogen, this time by the energy difference.

The enthalpy of reaction was also calculated based on the enthalpy values obtained, including a calculation with the final product, triethoxy (octadecyloxy) silane (Figure 4). 


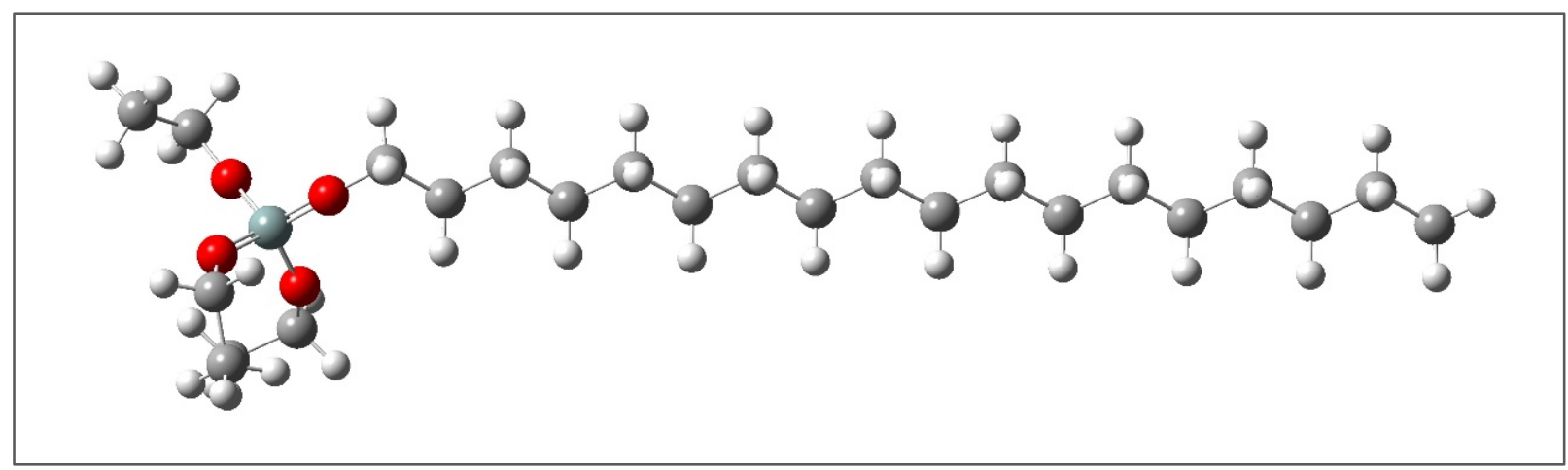

Figure 4 - Triethoxy (octadecyloxy) silane

Using the equation $\Delta \mathrm{H}=\mathrm{Hp}-\mathrm{Hr}$, where $\mathrm{Hp}$ is the enthalpy of the products and $\mathrm{Hr}$ a of the reactants, the value of $-235.40 \mathrm{Kcal} . \mathrm{mol}-1$ was obtained. This indicates that the reaction is exothermic.

\section{CONCLUSION}

The results obtained indicate a possible mechanism for the production of Trietoxi (octadecoxy) silane hydropergant, from the triethoxysilane compound and alcohol derived from linoleic acid (octadecanol), other calculations are being done to evaluate the interaction between the water repellant proposed in this study and substrates.

\section{ACKNOWLEDGMENTS}

Thanks to CNPq for the Scientific Initiation Grant of Luan Vieira Brito de Campos.

\section{REFERENCES}

Arruda, F. P.; Beltrão, N. E. M.; Andrade, A. P.; Pereira, W. E.; Severino, L. S. (2004). Cultivo do pinhão manso (Jatropha curcas L.) como alternativa para o semi-árido Nordestino. Revista Brasileira de Oleaginosas e Fibrosas. Campina Grande, PB. v. 8, n. 1, p. 789-99.

Drummond, A.R.F., Gazineu, M.H.P., Almeida, L., Souto Maior, A. Metanol e Etanol como Solventes na Extração do Óleo da 2008. Disponível:http://www.biodiesel.gov.br/docs/congresso2006/agricultura/metanol.pdf.

Mendes, M. F. (2002). Estudo do Processo da Concentração da Vitamina E presente no Destilado da Desodorização do Óleo de Soja usando $\mathrm{CO}_{2}$ Supercrítico. 2002. 103p. Tese de Doutorado em Engenharia Química- PEQ/COPPE, Universidade Federal do Rio de Janeiro, Rio de Janeiro.

Boss, E. A. (2000). Análise do desempenho de plantas de extração de óleos convencionais e de processos supercríticos, 2000. 121p.Dissertação de Mestrado em Engenharia Química - FEQ Universidade Estadual de Campinas, São Paulo. 
Purcino, A. A. C.; Drummond, O.A. (2004). Pinhão-manso. Belo Horizonte: EPAMIG, 7p, 1986 Apud Arruda, F. P.; Beltrão, N. E. M.; Andrade, A. P.; Pereira, W. E.; Severino, L. S. Cultivo do pinhão manso (Jatropha curcas L.) como alternativa para o semi-árido Nordestino. Revista Brasileira de Oleaginosas e Fibrosas, Campina Grande, PB. v.8, n. 1, p. 789-799.

Saturnino, H.M.; Pacheco, D.D.; Kakida, J.; Nagashi, T.; Gonçalves, N.P. (2005). Cultura do pinhãomanso (Jatropha curcas L.). Informe Agropecuário, Belo Horizonte, v.26, n.229, p.44-78.

Silva, C.F. (2006). Modelos matemáticos para o processo de transporte de massa na extração de produtos naturais de matrizes sólidas utilizando $\mathrm{CO}_{2}$ supercrítico: estudo experimental e teórico. 103p. 2006.Dissertação de Mestrado em Ciência de Alimentos, Programa de Pós Graduação em Ciência de Alimentos, Universidade Federal do Rio de Janeiro.

Mohini, M. (2009). Matéria baseada no Workshop promovido pela Associação Brasileira de Polímeros - ABPol em 3 de fevereiro de 2009, sobre Biorefineria, apresentado pelo Prof. Sain da Universidade de Toronto, Canadá.

Okamoto, M. ; Yamamoto, K. ; Suzuki, E. ; Ono, Y. (1993). Synthesis of trialkoxysilanes by the reaction of metallic silicone with alcohols using copper (I) chloride as the catalyst. Department of chemical engineering, Tokyo, Japan. 